\title{
In Planta Distribution of 'Candidatus Liberibacter asiaticus' as Revealed by Polymerase Chain Reaction (PCR) and Real-Time PCR
}

\author{
Satyanarayana Tatineni, Uma Shankar Sagaram, Siddarame Gowda, Cecile J. Robertson, \\ William O. Dawson, Toru Iwanami, and Nian Wang
}

First, second, third, fourth, fifth, and seventh authors: Citrus Research and Education Center, University of Florida, 700 Experiment Station Road, Lake Alfred 33850; sixth author: National Institute of Fruit Tree Science, Fujimoto 2-1, Tsukuba, Ibaraki 305-8605, Japan; and seventh author: Department of Microbiology and Cell Science, University of Florida, Gainesville 32611.

Current address of first author: United States Department of Agriculture-Agricultural Research Service, University of Nebraska, Lincoln 68583.

Accepted for publication 1 February 2008.

\begin{abstract}
Tatineni, S., Sagaram, U. S., Gowda, S., Robertson, C. J., Dawson, W. O., Iwanami, T., and Wang, N. 2008. In planta distribution of 'Candidatus Liberibacter asiaticus' as revealed by polymerase chain reaction (PCR) and real-time PCR. Phytopathology 98:592-599.

Huanglongbing (HLB) is one of the most devastating diseases of citrus worldwide, and is caused by a phloem-limited fastidious prokaryotic $\alpha$ proteobacterium that is yet to be cultured. In this study, a combination of traditional polymerase chain reaction (PCR) and real-time PCR targeting the putative DNA polymerase and 16S rDNA sequence of 'Candidatus Liberibacter asiaticus,' respectively, were used to examine the distribution and movement of the HLB pathogen in the infected citrus tree. We found

roots, and different floral and fruit parts, but not in endosperm and embryo, of infected citrus trees. Quantification analysis of the HLB bacterium indicated that it was distributed unevenly in planta and ranged from 14 to 137,031 cells/ $\mu$ g of total DNA in different tissues. A relatively high concentration of ' $\mathrm{Ca}$. Liberibacter asiaticus' was observed in fruit peduncles. Our data from greenhouse-infected plants also indicated that ' $C a$. Liberibacter asiaticus' was transmitted systemically from infection site to different parts of the plant. Understanding the distribution and movement of the HLB bacterium inside an individual citrus tree is critical for discerning its virulence mechanism and to develop management strategies for HLB.
\end{abstract} that ' $\mathrm{Ca}$. Liberibacter asiaticus' was distributed in bark tissue, leaf midrib,

Huanglongbing (HLB, formerly known as citrus greening) is one of the most destructive diseases of citrus, debilitating the productive capacity of citrus trees $(2,7)$. The disease is widespread in most areas of citrus-growing Asian countries, Africa, Brazil, and Florida (2). The HLB disease is caused by a fastidious $\alpha$-proteobacterium, Candidatus Liberibacter spp. The bacterium is phloem limited, transmitted by psyllid vectors, and has not been cultured yet $(6,10)$. Three species of HLB have been identified which differ in their vector specificity and environmental conditions: 'Candidatus Liberibacter asiaticus' is a heat-tolerant species vectored by both Diaphorina citri Kuwayama and Trioza erytreae Del Guercio; 'Ca. Liberibacter americanus' is a heattolerant species vectored by $D$. citri Kuwayama; and ' $C a$. Liberibacter africanus' is a heat-sensitive species and is transmitted by both $T$. erytreae Del Guercio and D. citri Kuwayama $(1,3,20)$.

$\mathrm{Ca}$. Liberibacter spp. inhabit the phloem sieve elements in infected plants and cause the disease by limiting sugar transport (N. Wang, unpublished data). Typical symptoms of HLB disease on citrus leaves of infected trees include reduced size, pale yellowing, blotchy mottle or variegated type of chlorosis with small upright leaves, followed by leaf drop and twig dieback at later stages (2). Some disease symptoms caused by HLB are similar to the symptoms caused by nutritional deficiencies. Anatomi-

Corresponding author: N. Wang; E-mail address: nianwang@crec.ifas.ufl.edu

doi:10.1094/PHYTO-98-5-0592

(C) 2008 The American Phytopathological Society
Additional keywords: citrus greening. cal analysis of HLB-affected sweet orange shoots with ' $C a$. Liberibacter africanus' indicated the association of disorder of the phloem and massive accumulation of starch in the plastids (22). However, it is unknown how $C a$. Liberibacter spp. spread throughout the tree and cause the disease.

The citrus HLB pathogen has yet to be cultured in vitro. Methods using DNA probes, enzyme-linked immunosorbent assay, electron microscopy (EM), and biological assay have been used to detect the HLB bacterium $(2,4,9,26)$. Lately, detection of $\mathrm{Ca}$. Liberibacter spp. is based mainly on conventional polymerase chain reaction (PCR) and quantitative real-time PCR (Q-PCR) with species-specific primers developed based on 16S rDNA and $\beta$-operon $(12,16,17)$. Detection of the HLB bacterium based on PCR methodology (PCR and Q-PCR) has gained popularity when compared with other methods due to its simplicity, sensitivity, and reliability. However, false negatives and false positives are common due to low titer of bacteria inside the phloem, presence of PCR amplification inhibitors in the phloem sap, and nonspecific amplification by PCR.

In the present study, a combination of traditional PCR and QPCR methods was used to examine the distribution and movement of the HLB bacterium inside an individual citrus tree, which is critical for understanding its virulence mechanism and to manage the spread of the disease. It was found that the HLB bacterium was distributed unevenly in bark tissue, leaf midribs, roots, and floral parts (petals, pistils, and stamens) and fruit parts (peduncle, columella, and seed coat), but failed to be detected in the endosperm and embryo of seed from infected plants. A relatively high concentration of HLB bacteria was found in fruit peduncles. Our 
data also suggested that $C a$. Liberibacter spp. were transmitted systemically from infection site to different parts of the plant through the phloem.

\section{MATERIALS AND METHODS}

Plant materials. HLB-infected tissue was collected from symptomatic and asymptomatic branches with flowers or young fruit or branches with mature fruit, and root samples from commercial citrus groves in South Florida during April to May, 2007. Total DNA was extracted from the tissue in a United States Department of Agriculture Animal and Plant Health Inspection Service/Center for Disease Control (USDA-APHIS/CDC)-approved secured laboratory at the Citrus Research and Education Center, University of Florida, Lake Alfred. To study the movement of the citrus HLB pathogen, young, healthy citrus plants were graft inoculated with budwood from HLB-infected citrus trees from the field, and kept in a USDA-APHIS/CDC-approved secured greenhouse at $28^{\circ} \mathrm{C}$. All young citrus plants used in greenhouse experiments were HLB-free before graft inoculation, based on PCR and Q-PCR tests.

Extraction of total DNA. Total DNA was extracted by grinding $250 \mathrm{mg}$ of tissue in liquid nitrogen into a fine powder. Subsequently, $2.5 \mathrm{ml}$ of buffer (50 mM Tris-Cl, pH 9.0;0.1 M NaCl; $10 \mathrm{mM}$ EDTA; and $2 \%$ sodium dodecyl sulfate [SDS]) was added and ground thoroughly. Extracted sap $(500 \mu \mathrm{l})$ was transferred to an Eppendorf tube and incubated at $65^{\circ} \mathrm{C}$ for $30 \mathrm{~min}$, followed by two phenol:chloroform extractions. Total DNA from $400 \mu \mathrm{l}$ of the aqueous phase was precipitated by adding two volumes of ethanol in the presence of $40 \mathrm{mM}$ sodium acetate, $\mathrm{pH}$ 5.2. The DNA pellets were suspended in $150 \mu$ of water.

Alternatively, the total DNA was extracted as described by Irey et al. (11). Briefly, $250 \mathrm{mg}$ of tissue was ground in $2.5 \mathrm{ml}$ of extraction buffer (100 mM Tris-Cl, pH 8.0; 50 mM EDTA; 500 $\mathrm{mM} \mathrm{NaCl} ; 1.5 \%$ SDS; and $10 \mathrm{mM}$ dithiothreitol). Extract $(1 \mathrm{ml})$ was transferred to an Eppendorf tube and incubated at $65^{\circ} \mathrm{C}$ for $30 \mathrm{~min}$. Subsequently, one-third volume of $5 \mathrm{M}$ potassium acetate was added, mixed thoroughly, and incubated on ice for $20 \mathrm{~min}$. The mixture was centrifuged for $10 \mathrm{~min}$ at 13,000 rpm, and DNA was precipitated from $0.4 \mathrm{ml}$ of supernatant by adding an equal volume of cold isopropanol. The tubes were incubated at $-20^{\circ} \mathrm{C}$ and the precipitated DNA was suspended in $150 \mu$ l of water.

Genomic DNA of bacterial strains from citrus was extracted with a Wizard Genomic DNA Purification Kit (Promega Corp., Madison, WI) according to the manufacturer's instructions.

PCR. Conventional PCR with SpeedSTAR HS DNA polymerase (Takara Bio USA, Madison, WI) and Go Taq Flexi DNA polymerase (Promega Corp.) was used to examine the presence of the HLB pathogen in different parts of citrus trees collected from the field and the greenhouse. A forward primer, HLB-65 (5'TCCTGAGAATTACACACAAAC), and a reverse primer, HLB66 (5'-TCTAAGTCTATCCTGTAACCC), designed based on the putative DNA polymerase gene (M94320) of the HLB bacterium (25) were used for PCR amplification in a $20-\mu 1$ reaction volume. The PCR reaction consisted of $1 \mu \mathrm{l}$ of DNA template, $0.2 \mu \mathrm{M}$ each oligonucleotide (HLB-65 and HLB-66), $0.25 \mathrm{mM}$ dNTPs, $1 \times$ buffer (FBII; Takara Bio USA), and $0.125 \mu \mathrm{l}(5 \mathrm{U} / \mu \mathrm{l})$ of SpeedSTAR HS DNA polymerase or Go Taq Flexi DNA polymerase and its corresponding buffer and was amplified by using the following protocol: $94^{\circ} \mathrm{C}$ for $2 \mathrm{~min}$; followed by 40 cycles at $94^{\circ} \mathrm{C}$ for $20 \mathrm{~s}, 54^{\circ} \mathrm{C}$ for $20 \mathrm{~s}$, and $72^{\circ} \mathrm{C}$ for $60 \mathrm{~s}$; followed by final extension at $72^{\circ} \mathrm{C}$ for $5 \mathrm{~min}$. PCR reaction $(15 \mu \mathrm{l})$ was analyzed through $1.0 \%$ agarose gel in $1 \times$ Tris-acetate-EDTA buffer (40 mM Tris, $20 \mathrm{mM}$ acetic acid, $1 \mathrm{mM}$ EDTA, $\mathrm{pH} 8.5$ ) and DNA bands were visualized by ethidium bromide staining. Additionally, we used a primer set in 16S rDNA, OI1/OI2c, specific to the ' $C a$. Liberibacter asiaticus' sp. (12) with the same conditions as mentioned for PCR with the HLB-65/HLB-66 primer set, except that both the annealing and extension temperatures were at $72^{\circ} \mathrm{C}$.

The conventional PCR and Q-PCR (see below) amplifications were repeated with all the samples at least three to five times, and the representation of one experiment is shown in Figure 1.

Q-PCR. Q-PCR was carried out with primers and probe for ' $\mathrm{Ca}$. Liberibacter asiaticus' essentially as described in Li et al. (16). Briefly, the real-time PCR amplifications were performed with ABI Prism 7000 Sequence Detection System (Applied Biosystems, Foster City, CA) using QIAGEN QuantiTect Probe PCR Kit (Qiagen, Valencia, CA) in a $25-\mu$ l reaction. The standard amplification protocol was $95^{\circ} \mathrm{C}$ for 15 min followed by 40 cycles at $94^{\circ} \mathrm{C}$ for $15 \mathrm{~s}$ and $58^{\circ} \mathrm{C}$ for $60 \mathrm{~s}$. All reactions were performed in triplicate with positive, healthy, and water controls, and the mean value of the threshold cycle $(\mathrm{Ct})$ was presented with standard deviation.

Development of a standard equation for quantification. The plasmid pLBA, which harbors the HLB-specific 16s rDNA, was constructed by cloning a 1,409-bp DNA fragment that was amplified using a universal primer rp1 (27) and Liberibacter-specific primer HLBrp (16) into pGEM T-easy vector (Promega Corp.). A standard equation was developed based on previous work by $\mathrm{Li}$ et al (16). The new standard equation was able to quantify bacterial populations as cells per microgram of total DNA rather than cells per microgram of plant tissue. The concentration and purity of DNA was determined using a Nanodrop spectrophotometer. The number of plasmid copies was calculated based on molecular weight using the formula number of copies $=$ (amount in nanograms $\times$ Avogadro's number)/(length in base pairs $\times 1 \times 10^{9} \times$ $650)$. The average weight of a base pair is assumed to be 650 daltons and Avogadro's number is $6.022 \times 10^{23}$. For example, $80 \mathrm{ng}$ of pLBA $(3,718 \mathrm{bp})$ consists of approximately $2 \times 10^{10}$ plasmids.

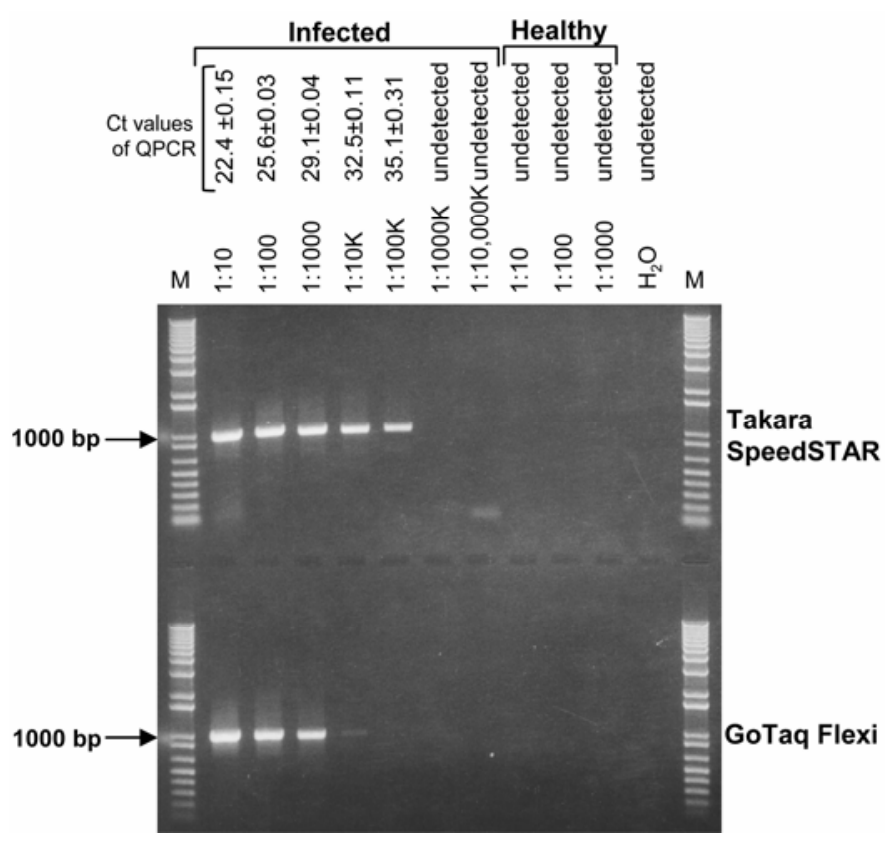

Fig. 1. Comparison of sensitivities of conventional polymerase chain reaction (PCR) and quantitative (Q)-PCR methods. Agarose gel electrophoresis of DNA amplified by SpeedSTAR HS DNA polymerase enzyme (Takara Bio USA) and Go Taq Flexi DNA polymerase enzyme (Promega Corp.) targeting the putative DNA polymerase gene sequence of 'Candidatus Liberibacter asiaticus.' Total DNA was extracted from bark from huanglongbing-infected and healthy sweet orange citrus trees and 10-fold serially diluted samples were used as templates for PCR amplification. Dilution of the templates used in PCR and Q-PCR and threshold cycle $(\mathrm{Ct})$ values obtained for Q-PCR targeting the $16 \mathrm{~S}$ rDNA are shown above the gel picture. M: DNA molecular weight size markers. 

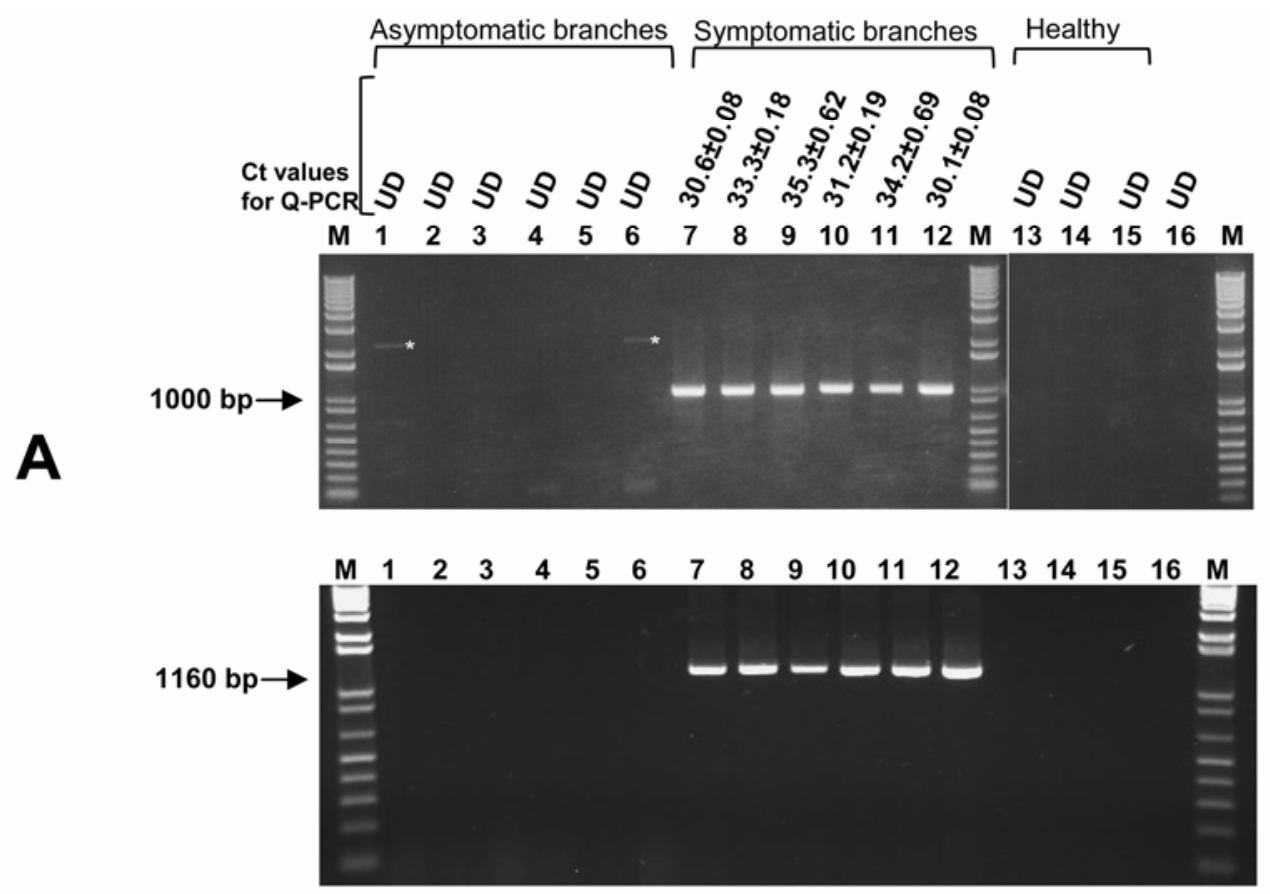

$\begin{array}{llllllllllllllllllll}M & 1 & 2 & 3 & 4 & 5 & 6 & 7 & 8 & 9 & 10 & 11 & 12 & 13 & 14 & 15 & 16 & 17 & 18 & M\end{array}$

\section{B}
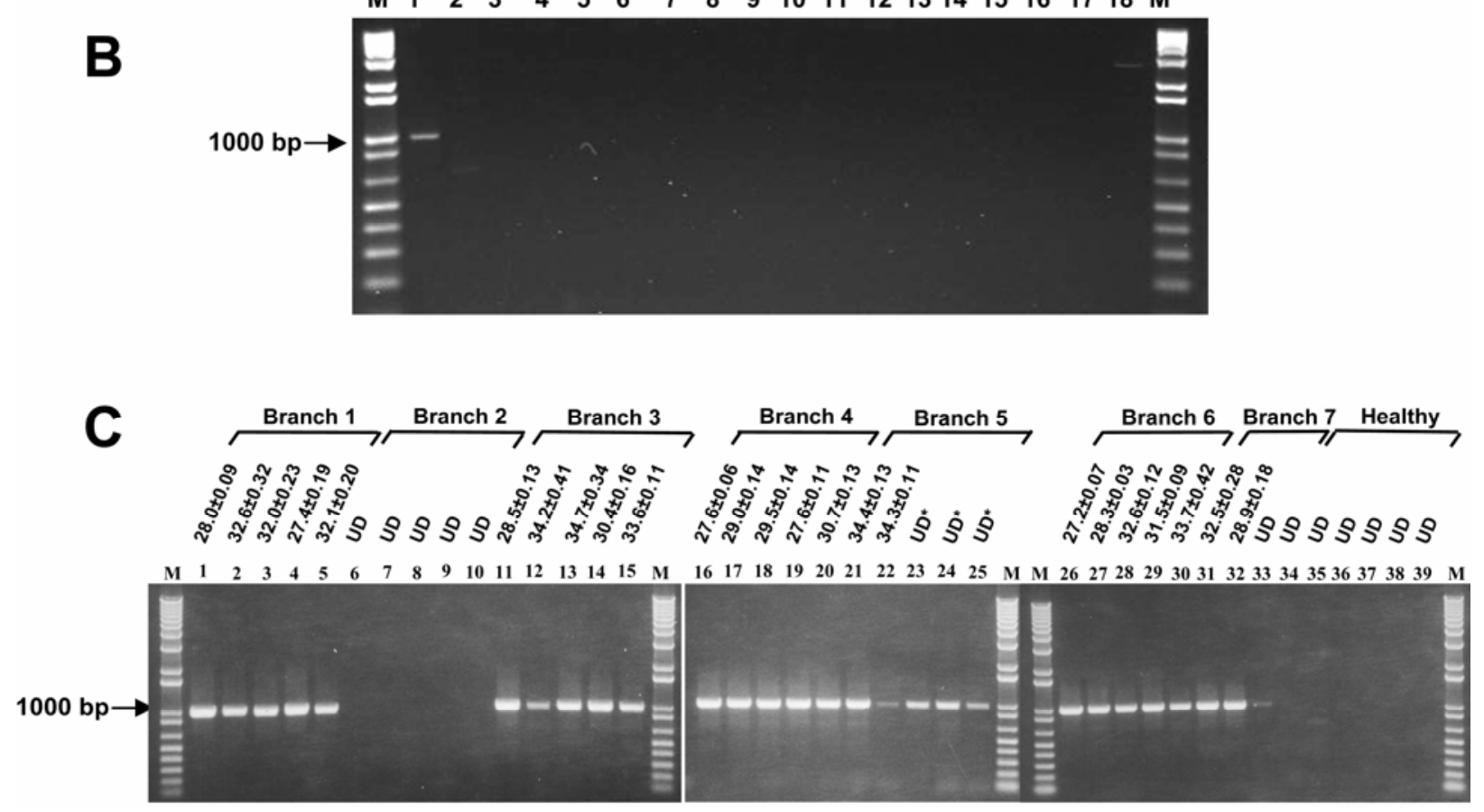

Fig. 2. Detection of the huanglongbing (HLB) bacterium in different parts of sweet orange. A, Leaf midribs (lanes 1, 4, 7, 10, and 13), petals (lanes 2, 5, 8, 11, and 14), and pistils $(3,6,9,12$, and 15). Lanes $1-3$ and 4-6: from two asymptomatic branches; lanes 7-9 and 10-12: from two symptomatic branches; lanes 13-15: from a healthy branch; lane 16: water control. SpeedSTAR HS DNA polymerase used for conventional polymerase chain reaction (PCR) amplification. The 1,000-bp fragments at the upper portion were amplified with HLB-65 and HLB-66. The 1,160-bp fragments at the lower portion were amplified with OI2c/OI1. The same samples were analyzed by quantitative (Q)-PCR targeting the 16S rDNA sequence of 'Candidatus Liberibacter asiaticus' and the threshold cycle (Ct) values are given above the gel picture. B, Specificity of the new primers HLB-65 and HLB-66. The specificity was evaluated with standard PCR using SpeedSTAR HS DNA polymerase with total DNA extracted from sweet orange plants infected with 'Ca. Liberibacter asiaticus' (lane 1), Citrus tristeza virus (lane 2), Xanthomonas axonopodis pv. citri (lane 3), Phytophthora sp. (lane 4), three HLB-free sweet oranges from different citrus groves containing multiple endophytes (lanes 5-7), 10 different bacterial isolates from citrus (lanes 8-17), and Mycosphaerella citri (lane 18). C, Detection of 'Ca. Liberibacter asiaticus' from bark tissue, leaf midrib, petals, pistils, and stamens collected from branches of HLB-infected citrus trees. Lanes 1, 6, 11, 16, 21, 26, 31, and 35: DNA extracted from bark tissue of branches; lanes 2, 7, 12, 17, 22, 27, 32, and 36: DNA extracted from leaf midribs of branches containing flowers; lanes 3, 8, 13, 18, 23, 28, 33, and 37: DNA extracted from floral petals; lanes 4, 9, 14, 19, 24, 29, 34, and 38: DNA extracted from pistils; lanes 5, 10, 15, 20, 25, 30, and 39: DNA extracted from stamens. Stamens were not included for DNA isolation from branch 7, because young flower buds were used for sampling. SpeedSTAR HS DNA polymerase used for conventional PCR amplification. Ct values of Q-PCR targeting the 16S rDNA sequence of ' $\mathrm{Ca}$. Liberibacter asiaticus' are presented above the gel picture. UD: undetected; M: DNA molecular weight size markers; *: false positive. 
False positives and false negatives. All samples were tested with conventional PCR and Q-PCR. A result was considered to be a false positive when it could not be confirmed with a second method even after optimization. Similarly, a result was considered to be a false negative when it turned out to be positive after optimization of its original condition or tested positive with two other sets of HLB-specific primers.

\section{RESULTS}

Comparison of traditional PCR and Q-PCR. Development of a sensitive and reliable diagnostic method is critical for early detection of the HLB bacterium in citrus trees, which is crucial for the management of the HLB disease. The sensitivity of conventional PCR using SpeedSTAR HS DNA polymerase and Go Taq Flexi DNA polymerase targeting the putative DNA polymerase sequence of ' $\mathrm{Ca}$. Liberibacter asiaticus' was compared with a real time-PCR method targeting the $16 \mathrm{~S}$ rDNA sequence of ' $\mathrm{Ca}$. Liberibacter asiaticus' using the DNA extracted from bark (Fig. 1). PCR with SpeedSTAR HS DNA polymerase was able to detect the HLB DNA up to a 1:100,000 dilution from bark, which was comparable to Q-PCR (Ct value of 35.1), whereas the PCR using Go Taq Flexi DNA polymerase detected up to 1:1,000 dilution and found a weak band at 1:10,000 dilution (Fig. 1). This clearly indicates that a nonoptimized PCR condition with a lowefficiency DNA polymerase enzyme will give false negatives at a low population of HLB bacteria. Both the Q-PCR and conventional PCR with SpeedSTAR HS DNA polymerase amplified the HLB DNA up to the 1:100,000 dilution (Fig. 1), suggesting that the sensitivity of the conventional PCR using SpeedSTAR HS DNA polymerase is comparable to that of Q-PCR. We also obtained similar levels of amplification with conventional PCR using SpeedSTAR HS DNA polymerase with OI1/OI2c primers (12) targeting the 16S rDNA of ' $C a$. Liberibacter asiaticus' (data not shown). No amplification was obtained from DNA extracted from healthy bark and water samples, as expected (Fig. 1).

The specificity of the assays with the new primers HLB65/HLB-66 was evaluated with standard PCR using SpeedSTAR HS DNA polymerase with total DNA extracted from sweet orange plants infected with ' $C a$. Liberibacter asiaticus,' Citrus tristeza virus (CTV), Xanthomonas axonopodis pv. citri, a Phytophthora sp., three HLB-free sweet oranges from different citrus groves containing multiple endophytes, 10 different bacterial strains from citrus from our previous study, and Mycosphaerella citri (Fig. 2B). The assays with primers HLB-65/HLB-66 generated positive results only from samples infected with ' $\mathrm{Ca}$. Liberibacter asiaticus'. The fragments were cloned and sequenced. Sequencing results showed $100 \%$ identity to the ' $\mathrm{Ca}$. Liberibacter asiaticus' sp. No detectable band was observed for all other samples, except one weak band for $M$. citri with a much larger size. Our previous study indicated there were more than 10 bacteria associated with citrus, including Bacillus spp., Microbacterium spp., Sphingomonas spp., Hymenobacter spp., Rhodococcus spp., and Pantoea agglomerans. None of the bacteria reacted with the primers. For all the samples tested positive with HLB-65/HLB-66, the samples also were positive with OI1/OI2c, and vise versa (Fig. 2A).

One false positive was found with traditional PCR targeting the DNA polymerase gene, and two false-positive samples were found with Q-PCR targeting 16S rDNA from 33 field-collected samples (data not shown). False negatives also were observed with both methods (data not shown). In order to avoid the false positive or false negative effect with the use of any one detection method, we combined both PCR and Q-PCR methods to detect ' $C a$. Liberibacter asiaticus' in infected plants in this study.

Detection of ' $\mathrm{Ca}$. Liberibacter asiaticus' in different floral parts of infected trees. In order to understand the relationship between ' $\mathrm{Ca}$. Liberibacter asiaticus' localization and the development of HLB disease, different parts of citrus trees were examined with conventional PCR using high-efficiency SpeedSTAR HS DNA polymerase targeting the HLB DNA polymerase sequence and Q-PCR targeting the 16S rDNA sequence of ' $\mathrm{Ca}$. Liberibacter asiaticus'. First, the presence of ' $\mathrm{Ca}$. Liberibacter asiaticus' in leaf midribs, floral petals, and pistils was examined from symptomatic and asymptomatic branches of infected citrus trees from the field. The HLB bacterium was readily detected in leaf midribs, petals, and pistils of symptomatic branches (Fig. 2A, lanes 7 to 12), whereas we failed to amplify the HLB-specific DNA at detectable levels from asymptomatic branches from the same infected trees (Fig. 2A, lanes 1 to 6). However, in a separate collection from other trees, ' $\mathrm{Ca}$. Liberibacter asiaticus' was detected from asymptomatic young leaves of infected trees (data not shown). The $\mathrm{Ct}$ value ranged from 22.3 to 26.1 and 23.2 to 25.0 for asymptomatic tissues and symptomatic tissues, respectively.

The distribution of ' $\mathrm{Ca}$. Liberibacter asiaticus' was further examined in bark tissue, leaf midribs, petals, pistils, and stamens from infected field trees as described above. Of seven branches collected, six branches were positive for ' $\mathrm{Ca}$. Liberibacter asiaticus' with varied concentrations in all assayed parts (Fig. 2C; Table 1). Our data suggest that the HLB bacterium is distributed in all assayed floral parts, including petals and stamens (Fig. 2C; Table 1). 'Ca. Liberibacter asiaticus' was examined for its presence in young, immature floral parts such as petals and pistils, but was not examined in the stamens from young flower buds. A weak PCR amplification was obtained from the petals of young flowers but no HLB bacterium was detected in young pistils by either conventional PCR using HLB-65 and HLB-66 primers or Q-PCR, despite a high concentration of HLB bacterium found in the bark tissue and leaf midribs (Fig. 2C, branch 7).

TABLE 1. Quantification of 'Candidatus Liberibacter asiaticus' from different parts of huanglongbing-infected citrus trees by quantitative polymerase chain reaction assay ${ }^{\mathrm{Z}}$

\begin{tabular}{|c|c|c|c|c|}
\hline \multirow[b]{2}{*}{ Tissue } & \multirow[b]{2}{*}{ No. of samples tested } & \multirow[b]{2}{*}{ No. tested positive } & \multicolumn{2}{|c|}{ 'Ca. Liberibacter asiaticus' cells/ $\mu \mathrm{g}$ of total DNA } \\
\hline & & & Mean \pm SE & Population range \\
\hline Root & 8 & 8 & $10,331 \pm 5,398 \mathrm{~B}$ & $1,837-47,414$ \\
\hline Leaf midrib & 8 & 8 & $6,693 \pm 3,528 \mathrm{~B}$ & $159-27,666$ \\
\hline Pistil & 8 & 6 & $3,189 \pm 1,523 \mathrm{~B}$ & $14-8,047$ \\
\hline Stamen & 6 & 4 & $1,177 \pm 699 \mathrm{~B}$ & $337-3,253$ \\
\hline Peduncle & 7 & 7 & $67,764 \pm 16,559 \mathrm{~A}$ & $18,364-13,7031$ \\
\hline Young whole fruit & 8 & 7 & $1,873 \pm 1,222 \mathrm{~B}$ & $53-9,200$ \\
\hline Bark & 6 & 6 & $16,639 \pm 6,837 \mathrm{~B}$ & $254-45,499$ \\
\hline
\end{tabular}

${ }^{\mathrm{z}}$ Bacterial populations are presented as the mean of independent assays followed by the standard error (SE) of mean. Different letters indicate statistically significant differences $(P<0.05)$. Differences between different tissues were determined by SAS (SAS, Cary, NC) using the general linear model procedure, and significantly different means $(P<0.05)$ were separated by the LS means method. 
Three false negatives were observed from branch 5, which failed to detect with the Q-PCR; however, the conventional PCR with primers specific to the putative DNA polymerase sequence of ' $\mathrm{Ca}$. Liberibacter asiaticus' amplified fairly strong DNA bands (Fig. 2C, lanes 23 to 25). Similar levels of amplification were obtained with primers specific to the $16 \mathrm{~S}$ rDNA sequence of ' $\mathrm{Ca}$. Liberibacter asiaticus' (data not shown).

Detection of ' $\mathrm{Ca}$. Liberibacter asiaticus' in different parts of mature fruit. In an attempt to study whether ' $\mathrm{Ca}$. Liberibacter asiaticus' found in flower pistils would be present further inside fruit, young fruit and various parts of mature fruit were examined for the presence of the HLB bacterium. Samples were collected randomly for young fruit (4 to $8 \mathrm{~mm}$ in diameter) from HLBinfected field trees, and ' $\mathrm{Ca}$. Liberibacter asiaticus' was detected in all nine young fruit samples assayed (Fig. 3B; Table 1), which suggests that the HLB pathogen detected in floral parts was retained and advanced to young fruit during fruit development. The PCR products with HLB65/66 and OI1/OI2c amplified from fruits were cloned and the sequencing data showed $100 \%$ identity to ' $C a$. Liberibacter asiaticus.'

The distribution of the HLB bacterium was examined in different parts of mature fruit collected from infected field trees. These samples included fruit peduncles, columella, seed coat, and endosperm and embryo from seven randomly collected fruit by conventional PCR and Q-PCR (Fig. 3A, fruit 1 to 27). ' $C a$. Liberibacter asiaticus' was detected in fruit peduncle $(\mathrm{Ct}$ value 25.4 to 27.2), columella ( $\mathrm{Ct}$ value 27.9 to 32.5 ), and seed coat $(\mathrm{Ct}$ value 29.3 to 33.8 ). However, ' $\mathrm{Ca}$. Liberibacter asiaticus' was not detected in the seed endosperm and embryo. The faint band that appeared in the endosperm and embryo of fruit 5 (Fig. 3A, lane 20) might be due to incomplete removal of seed coat from the endosperm and embryo. Additionally, aborted seed from HLB- infected fruit was examined and the HLB bacterium was found at high concentrations (data not shown). Our data suggest that the HLB bacterium moved from floral parts to different parts of mature fruit during morphogenesis.

Quantitative analysis of the HLB bacterial population in different parts of citrus. In order to further understand the in planta distribution of the HLB bacterium, a standard equation, $y=$ $-0.3101 x+12.09\left(R^{2}=0.99941\right)$, was developed based on previous work by $\mathrm{Li}$ et al. (16). The new standard equation was able to quantify the bacterial population as cells per microgram of total DNA, which will eliminate the potential variation in the DNA extraction process. The effect of potential Q-PCR inhibitors in the DNA extracts was tested by running spiked samples before and after DNA extraction. Basically, $1 \mu \mathrm{g}$ of plasmid DNA pLBA containing the ' $C a$. Liberibacter asiaticus' $16 \mathrm{~S}$ gene was added before or after the DNA extraction procedure of the healthy plant samples. Q-PCR assays were performed to compare the $\mathrm{Ct}$ value with or without spiked samples. No significant inhibitory effect was observed for both methods (Fig. 4). Analysis of variance also indicated that both DNA extraction methods have no significant inhibitory effect on Q-PCR assays at the given condition.

The standard equation $y=-0.3101 x+12.09\left(R^{2}=0.99941\right)$ was used to convert the individual $\mathrm{Ct}$ values into bacterial population as cells per microgram of total DNA (Table 1). Quantification analysis of the HLB bacterium indicates that it was unevenly distributed in planta and ranged from 14 to 137,031 cells/ $\mu \mathrm{g}$ of total DNA in different tissues. This represented an $\approx 10,000$ times difference in the HLB population in different parts of the plant. The HLB bacterium was most abundant in the peduncle $(67,764$ cells/ $\mu$ g of total DNA), followed by bark $(16,639$ cells/ $\mu \mathrm{g}$ of total DNA), root $(10,331 \mathrm{cells} / \mu \mathrm{g}$ of total

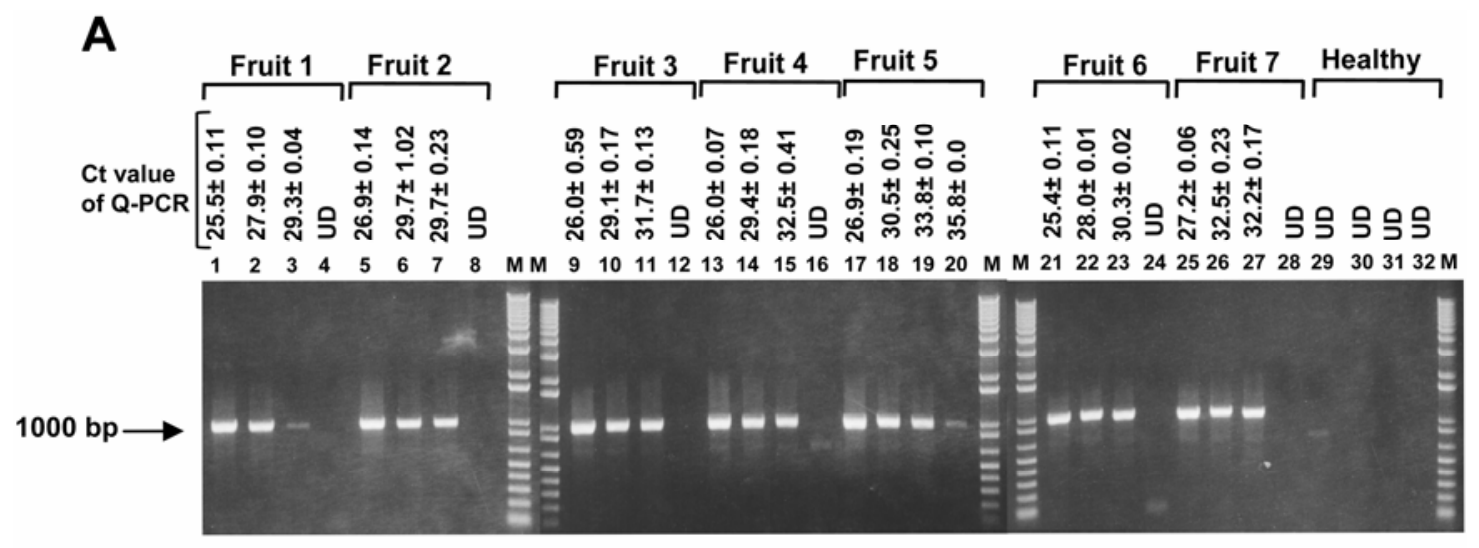

B

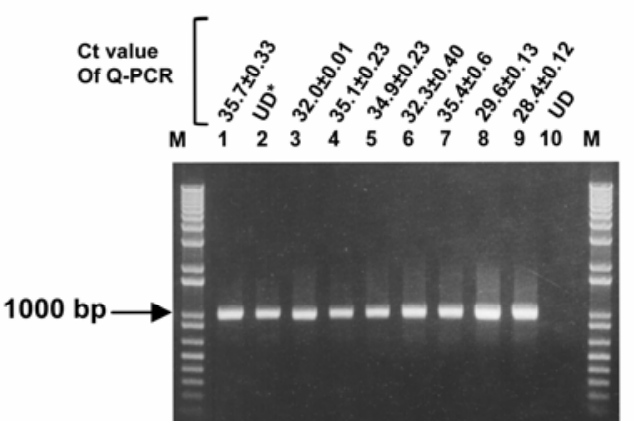

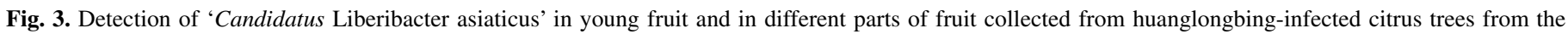

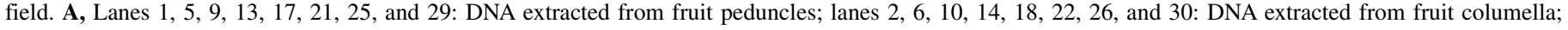

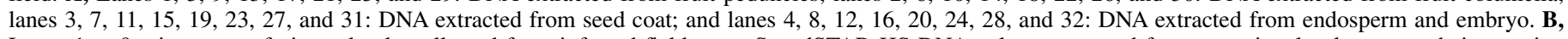

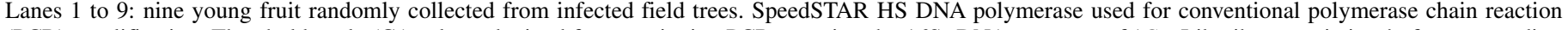

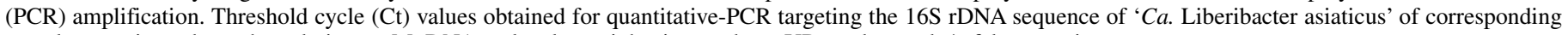
samples are given above the gel picture. M: DNA molecular weight size markers. UD: undetected; *: false negative. 


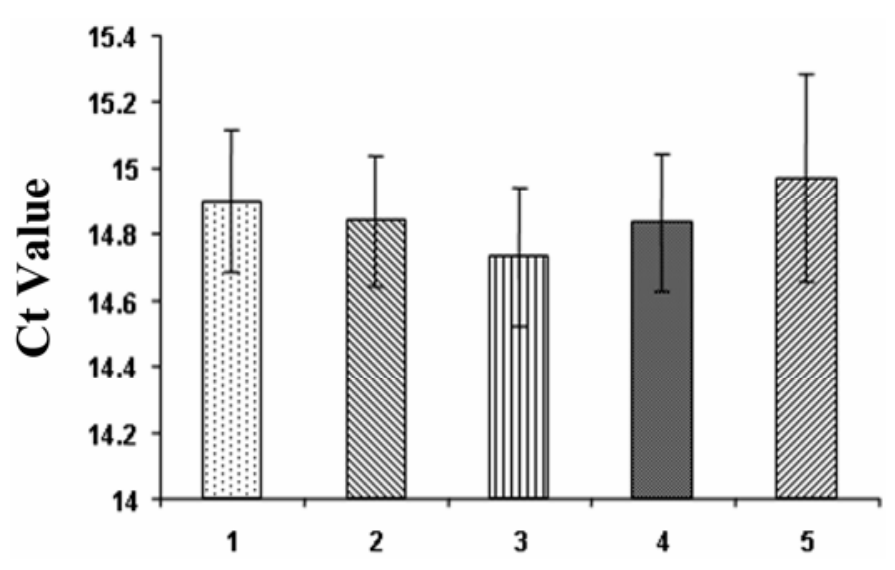

Fig. 4. Effect of potential inhibitors on quantitative polymerase chain reaction assays. Column 1: $1 \mu \mathrm{g}$ of pLBA plasmid was diluted into $150 \mu \mathrm{l}$ of water; column 2: $1 \mu \mathrm{g}$ of pLBA plasmid was added into $250 \mathrm{mg}$ of healthy sweet orange midrib before extraction and purified with the first method described for total DNA extraction and suspended into $150 \mu \mathrm{l}$ of water; column 3: $1 \mu \mathrm{g}$ of pLBA plasmid was added into $250 \mathrm{mg}$ of healthy sweet orange midrib before extraction and purified with the Irey method described for total DNA extraction and suspended into $150 \mu \mathrm{l}$ of water; column 4: $1 \mu \mathrm{g}$ of pLBA plasmid was added after the extraction of the $250 \mathrm{mg}$ of healthy sweet orange midrib with the first method described for total DNA extraction and suspended into $150 \mu \mathrm{l}$ of water; column 5: $1 \mu \mathrm{g}$ of pLBA plasmid was added after the extraction of the $250 \mathrm{mg}$ of healthy sweet orange midrib with the Irey method described for total DNA extraction and suspended into $150 \mu$ of water. Each treatment was repeated for three times.
DNA), leaf midrib $(6,693$ cells/ $\mu$ g of total DNA), columella $(4,279$ cells $/ \mu \mathrm{g}$ of total DNA), pistil $(3,189$ cells/ $\mu \mathrm{g}$ of total DNA), seed coat $(2,576$ cells/ $\mu$ g of total DNA), young fruit $(1,873$ cells $/ \mu \mathrm{g}$ of total DNA), stamen (1,177 cells/ $\mu \mathrm{g}$ of total DNA), and petal $(707$ cells/ $\mu \mathrm{g}$ of total DNA). However, statistical analysis indicated that the HLB bacterial density was significantly higher than in the rest of the tissues only in peduncle. There was no significant difference in bark, root, leaf midrib, columella, pistil, seed coat, young fruit, stamen, and petal.

Systemic transmission of ' $\mathrm{Ca}$. Liberibacter asiaticus' in citrus trees. In order to characterize the movement of ' $\mathrm{Ca}$. Liberibacter asiaticus' inside the phloem, young citrus trees were graft inoculated with budwood from HLB-infected citrus trees from the field and grown in a greenhouse. We examined the presence of ' $C a$. Liberibacter asiaticus' from fully expanded young leaves to mature leaves from a branch away from the inoculation site 8 months after graft inoculation. In all, four samples were collected from a branch per cultivar. The cultivars included Citrus macrophylla, Mexican lime (C. aurantifolia (Christm.) Swing), Duncan grapefruit (C. paradisi Macf.), Madam vinous sweet orange $(C$. sinensis $(\mathrm{L}))$, and citron $(C$. medica $\mathrm{L}$.). The presence of the HLB bacterium was examined from these samples using conventional PCR and Q-PCR. In all assayed samples, the HLB bacterium was detected from all tested leaves away from the inoculation site, except for one mature leaf sample (Fig. 5A). ' $C a$. Liberibacter asiaticus' also was detected in roots from greenhouse-infected citrus plants with PCR and Q-PCR (data not shown). The PCR products with HLB65/66 and OI1/OI2c from
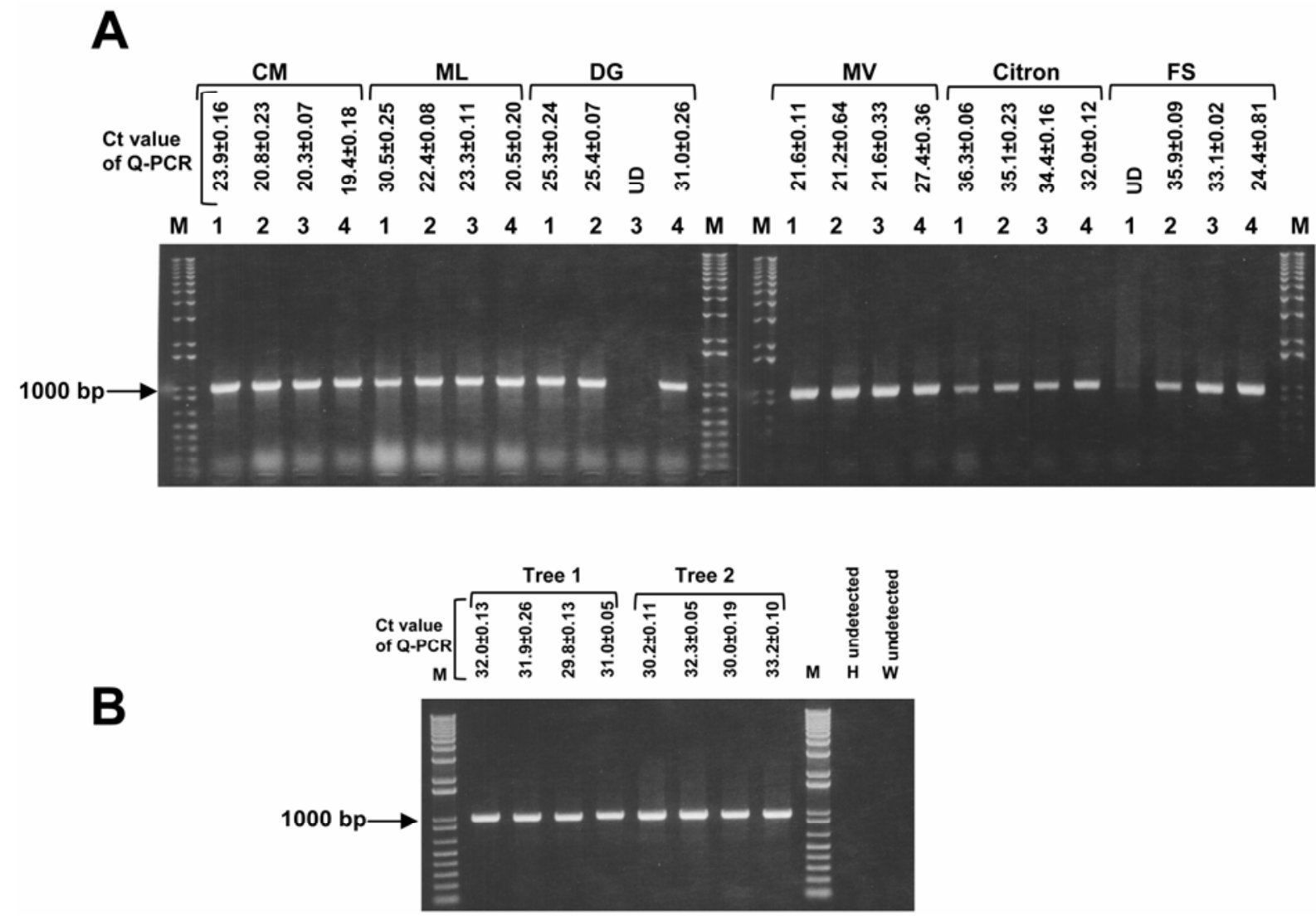

Fig. 5. Movement of the huanglongbing (HLB) bacterium from the inoculation site to different parts of the plant. A, Distribution of 'Candidatus Liberibacter asiaticus' in the branches of Citrus macrophylla (CM), Mexican lime (ML), Duncan grapefruit (DG), Madam vinous (MV), and citron plants from the greenhouse, and a field-collected sweet orange branch (FS). Three leaves per sample, starting with fully expanded first leaf, and four samples in all were collected from a branch per cultivar. Lanes 1 to 4: youngest leaves to mature leaves of a branch. B, Detection of ' $\mathrm{Ca}$. Liberibacter asiaticus' in roots collected from HLB-infected citrus trees from the field. DNA templates from four independent root samples collected per tree were used in polymerase chain reaction (PCR) amplifications. SpeedSTAR HS DNA polymerase used for conventional PCR amplification. Threshold cycle (Ct) values obtained for quantitative (Q)-PCR targeting the 16S rDNA sequence of ' $\mathrm{Ca}$. Liberibacter asiaticus' are shown above the gel picture. H: root samples from the healthy tree; W: water control; M: DNA molecular size markers. 
roots were cloned and the sequencing data showed $100 \%$ identity to ' $\mathrm{Ca}$. Liberibacter asiaticus'.

The possible movement of ' $\mathrm{Ca}$. Liberibacter asiaticus' from inoculation site to different parts of the plant in citrus trees was investigated further by examining the roots from HLB-infected field trees. In total, eight root samples, four samples per tree, were collected from two symptomatic field trees, and total DNA was used as template for conventional PCR and Q-PCR. The presence of ' $\mathrm{Ca}$. Liberibacter asiaticus' in the roots of infected trees was observed using both conventional PCR and Q-PCR (Fig. 5B; Table 1). The $\mathrm{Ct}$ value of the root samples from HLB-infected trees ranged from $29.8 \pm 0.13$ to $33.2 \pm 0.1$ (Fig. $5 \mathrm{~B}$ ).

\section{DISCUSSION}

The current management strategy of HLB is to remove infected citrus trees and reduce psyllid populations with insecticides. This strategy requires sensitive and reliable diagnostic methods, ideally with tissue containing a relatively high concentration of the HLB bacterium for early detection. In this study, we found that a combination of conventional PCR and Q-PCR was an effective method for the detection of ' $\mathrm{Ca}$. Liberibacter asiaticus' that would minimize false positives and negatives, thus increasing its sensitivity and reliability. We examined the distribution of the HLB bacterium in different parts of infected citrus trees and found that ' $\mathrm{Ca}$. Liberibacter asiaticus' was detected in all floral parts (petals, pistils, and stamens) and fruit parts (peduncle, columella, and seed coat), except in endosperm and embryo.

$\mathrm{Ca}$. Liberibacter spp. are closely associated with typical symptoms of an infected citrus tree (1). Failure to detect ' $\mathrm{Ca}$. Liberibacter asiaticus' from asymptomatic branches of infected trees might be due to the asymptomatic branch being free from the HLB pathogen, or having a bacterial population density that is too low to detect using the current methods. Our data provides experimental evidence that the HLB bacterium is unevenly distributed in citrus trees (10). The HLB bacterium population ranged from 14 to 137,031 cells/ $\mu$ g of total DNA in different tissues, representing an $\approx 10,000$-fold difference in bacterial population density as observed in different organs of the plant (Table 1). This signifies the necessity of choosing samples carefully for diagnostic purposes. The high HLB bacterial population in fruit peduncle makes it a target for sensitive detection of the HLB bacterium and prevents its spread at early stage. Even though no obvious symptoms were observed on floral parts, the HLB bacterium was detected in petals, pistils, and stamens of flowers collected from infected trees (Fig. 2C; Table 1). The HLB bacterium was detected in small, young fruit and different fruit parts such as peduncles, columella, and seed coat (Fig. 3; Table 1). A previous report indicated that the HLB bacterium was seed transmitted even though we do not understand how the HLB bacterium enters the phloem of the seedling (24). Further study is needed to address the seed transmission because the previous study on seed transmission was based solely on symptoms and was not confirmed with PCR and other means. Other bacteria, such as Xylella fastidiosa (18), Erwinia stewartii (14), and Phytoplasma (13), have been found in the seed. Detection of the citrus HLB pathogen inside the fruit and seed has important implications in preventing the spread of the citrus HLB disease. The distribution pattern of ' $C a$. Liberibacter asiaticus' in planta was similar to the causal agent of mulberry dwarf phytoplasma which was found in leaves, flowers, fruit, seed coats, and roots (5). This might be due to the fact that both the HLB bacterium and Phytoplasma are phloem-limited bacteria.

It is not surprising that the citrus HLB pathogen moves from inoculation site to different parts of the plant. Detection of ' $\mathrm{Ca}$. Liberibacter asiaticus' in sink organs such as young leaves, fruit, flowers, and roots from infected citrus trees is a good indication of its direction of movement within phloem. We cannot rule out the possibility of multiple infections of different branches of citrus trees by psyllid transmissions (2). With the only source of infection being the graft inoculum, the greenhouse experiments demonstrated the systemic movement of pathogen from the site of infection to different parts of the plant. Detection of ' $\mathrm{Ca}$. Liberibacter asiaticus' inside the bark tissue, leaf midribs, and roots from infected citrus trees clearly indicated that the pathogen is transferred systemically with the continuous sieve tube system. The detection of the HLB bacterium in roots can explain why many symptomless trees pruned to the stump level developed HLB symptoms in new growth flushes (19). The citrus HLB pathogen is $\approx 2 \mu \mathrm{m}$ long and 0.1 to $0.2 \mu \mathrm{m}$ in diameter (15). The pores on the sieve plates range from a fraction of a micron to $\approx 14 \mu \mathrm{m}$ (8). Observation with an EM also indicates that $\mathrm{Ca}$. Liberibacter spp. can move through the sieve plate pore (data not shown). Consequently, the pathogen can move freely through the sieve pores along with the assimilate flow from leaves to sugarconsuming plant organs, as observed with phytoplasma $(5,13)$. However, it is not known whether the citrus HLB bacterium can pass through the pore-plasmodesmata unit between the sieve element and the companion cell because they are much smaller (5). Interestingly, phytoplasma was documented in both companion cells and phloem parenchyma cells, even though the mechanism of movement into phloem-related cells remains unknown $(17,23)$. HLB bacteria could block the movement of nutrients inside the phloem and, potentially, enhance the severity of the disease by forming aggregates. It also is possible that the HLB pathogen might secrete virulence factors or toxins into the phloem, thus affecting the host response and causing the HLB disease.

\section{ACKNOWLEDGMENTS}

This research was supported in grants from the Florida Citrus Production Research Advisory Council (FCPRAC). We thank M. Afunian and T. Shilts for their technical help, J. Cook for editorial assistance, and M. Sagaram for her assistance with statistics.

\section{LITERATURE CITED}

1. Bové, J. M. 2006. Huanglongbing: A destructive, newly-emerging, century-old disease of citrus. J. Plant Pathol. 88:7-37.

2. Bové, J. M., Calavan, E. D., Capoor, S. P., Cortez, R. E., and Schwarz, R. E. 1974. Influence of temperature on symptoms of California stubborn, South African greening, Indian citrus decline and Philippine leaf mottling disease. Pages 12-15 in: Proc. 6th Conf. Int. Organ. Citrus Virologists, IOCV, Riverside, CA.

3. Capoor, S. P., Rao, D. G., and Viswanath, S. M. 1967. Diaphorina citri Kuway., a vector of the Huanglongbing disease of citrus in India. Indian J. Agric. Sci. 37:572-576.

4. Catling, H. D., Garnier, M., and Bové, J. M. 1978. Presence of citrus greening disease in Bangladesh and a new method for rapid diagnosis. FAO Plant Prot. Bull. 26:16-18.

5. Christensen, N. M., Nicolaisen, M., Hansen, M., and Schulz, A. 2004 Distribution of phytoplasmas in infected plants as revealed by Real-Time PCR and bioimaging. Mol. Plant-Microbe Interact. 17:1175-1184.

6. Da Graca, J. V. 1991. Citrus greening disease. Annu. Rev. Phytopathol. 29:109-136.

7. Da Graca, J. V., and Korsten, L. 2004. Citrus huanglongbing: Review, present status and future strategies. Pages 229-245 in: Diseases of Fruits and Vegetables, Vol. 1. S. A. M. H. Naqvi, ed. Kluwer Academic, Dordrecht, The Netherlands.

8. Easu, K., and Cheadle, VI. 1959. Size of pores and their contents in sieve elements of dicotyledons. Proc. Natl. Acad. Sci. USA 45: 156-162.

9. Garnier, M., Gao, S. J., He, Y., Villechanoux, S., Gandar, J., and Bové, J. M. 1991. Study of the greening organism (GO) with monoclonal antibodies: serological identification, morphology serotypes and purification of the GO. Pages 428-435 in: Proc. 11th Conf. Int. Organ. Citrus Virologists. IOCV, Riverside, CA.

10. Halbert, S. E., and Manjunath, K. L. 2004. Asian citrus psyllid (Sternorrhycha: Psyllidae) and greening disease of citrus: A literature review and assessment of risk in Florida. Fla. Entomol. 87:330-353.

11. Irey, M. S., Gast, T., and Gottwald, T. 2006. Comparison of visual assessment and polymerase chain reaction assay testing to estimate the incidence of the huanglongbing pathogen in commercial Florida citrus. 
Proc. Fla. State Hortic. Soc. 42:17-21.

12. Jagoueix, S., Bové, J. M., and Garnier, M. 1996. PCR detection of the two 'Candidatus' Liberibacter species associated with greening disease of citrus. Mol. Cell. Probes 10:43-50.

13. Jiang, H., Wei, W., Saiki, T., Kawakita, H., Watanabe, K., and Sato, M. 2004. Distribution patterns of mulberry dwarf phytoplasma in reproductive organs, winter buds, and roots of mulberry trees. J. Gen. Plant Pathol. 70:168-173.

14. Khan, A., Ries, S. M., and Pataky, J. K. 1996. Transmission of Erwinia stewartii through seed of resistant and susceptible field and sweet corn. Plant Dis. 80:398-403.

15. Laflèche, D., and Bové, J. M. 1970. Structures de type mycoplasme dans les feuilles d'orangers atteints de la maladie du greening. C. R. Acad. Sci. Ser. D 270:455-465.

16. Li, W. B., Hartung, J. S., and Levy, L. 2006. Quantitative real-time PCR for detection and identification of Candidatus Liberibacter species associated with citrus huanglongbing. J. Microbiol. Methods 66:104-115.

17. Li, W. B., Hartung, J. S., and Levy, L. 2007. Evaluation of DNA amplification methods for improved detection of "Candidatus Liberibacter species" associated with citrus huanglongbing. Plant Dis. 91:51-58.

18. Li, W. B., Pria, W. D., Jr., Lacava, P. M., Qin, X., and Hartung, J. S. 2003. Presence of Xylella fastidiosa in sweet orange fruit and seed and its transmission to seedlings. Phytopathology 93:953-958.

19. Lopes, S. A., Frare, G. F., Yamamoto, P. T., Ayres, A. J., and Barbosa, J. C. 2007. Ineffectiveness of pruning to control citrus huanglongbing caused by Candidatus Liberibacter americanus. Eur. J. Plant Pathol. 119:463-468

20. McClean, A. P. D., and Oberholzer, P. C. J. 1965. Citrus psylla, a vector of the greening disease of sweet orange. S. Afr. J. Agric. Sci. 8:297-298.

21. Rudzinska-Langwald, A., and Kaminska, M. 1999. Cytopathological evidence for transport of phytoplasma in infected plants. Acta Soc. Bot. Pol. 68:261-266.

22. Schneider, H. 1968. Anatomy of greening-diseased sweet orange shoots. Phytopathology 58:1155-1160.

23. Siller, W., Kuhbandner, B., Marwitz, R., Petzold, H., and Seemüller, E. 1987. Occurrence of mycoplasma-like organisms in parenchyma cells of Cuscuta odorata (Ruiz et Pav.). J. Phytopathol. 119:147-159.

24. Tirtawidjaja, S. 1981. Insect, dodder and seed transmissions of citrus vein phloem degeneration (CVPD). Proc. Int. Soc. Citricult. 1:469-471.

25. Villechanoux, S., Garnier, M., Laigret, F., Renaudin, J., and Bové., J. M. 1993. The genome of the non-cultured, bacterial-like organism associated with citrus greening disease contains the nusG-rplKAJL-rpoBC gene cluster and the gene for a bacteriophage type DNA polymerase. Curr. Microbiol. 26(3):161-166.

26. Villechanoux, S., Garnier, M., Renaudin, J., and Bové. J. M. 1992. Detection of several species of the bacterium-like organism of citrus greening disease by DNA probes. Curr. Microbiol. 24:89-95.

27. Weisburg, W. G., Barns, S. M., Pelletier, D. A., and Lane, D. J. 1991. 16S ribosomal DNA amplification for phylogenetic study. J. Bacteriol. 173:697-703. 